\title{
PEMANFAATAN KEADAAN GEOGRAFIS WILAYAH JEMBER SEBAGAI MEDIA PEMBELAJARAN KONSEP IPA
}

\author{
Nurul Rochaini \\ Program Studi Pendidikan IPA, Fakultas Keguruan Dan Ilmu Pendidikan, Universitas \\ Jember, Indonesia \\ Jln. Kalimantan 37, Jember 68121 \\ e-mail : rochaininurul@gmail.com
}

\begin{abstract}
Abstrak: dari segi topografi, wilayah kabupaten jember bagian utara merupakan wilayah dataran tinggi, sedangkan wilayah jember bagian selatan merupakan wilayah dataran rendah dan pesisir. Ketinggian yang berbeda berpengaruh pada flora dan fauna nya. Dari keadaan alam tersebut dapat digunakan sebagai bahan pembelajaran sains. Penelitian ini bertujuan untuk menemukan gagasan baru dalam metode pembelajaran dengan memanfaatkan alam sekitar sebagai medianya. Sehingga dapat tercipta suasana belajar yang menyenangkan untukpeserta didik.
\end{abstract}

Kata Kunci: topografi, flora dan fauna.

Abstract: In terms of topography, the northern part of Jember Regency is a highland region, while the southern part of Jember is a lowland and coastal area. Different heights of flora and fauna. From natural conditions that can be used as material for learning science. This study aims to find new information in learning methods by using the environment as a medium. You can learn a variety of fun learning for students.

Keyword: topography, flora and fauna.

\section{PENDAhUluAN}

Dari segi topografi sebagian Kabupaten Jember di wilayah bagian selatan merupakan dataran rendah yang relatif subur untuk pengembangan tanaman pangan, sedangkan di bagian utara merupakan daerah perbukitan dan bergunung-gunung yang relatif baik bagi pengembangan tanaman keras dan tanaman perkebunan. Hal itu menyebabkan banyaknya variasi pada tumbuhan. Selain itu banyak hewan-hewan yang ada di pesisir pantai. Keanekaramanan ini dapat gunakan sebagai media pembelajaran sains.

Belajar adalah kegiatan yang penuh risiko. Siswa dapat memilih jalan mereka sendiri, tetapi di sini ada peran guru yang mengiringi mereka. Bukan untuk menyamai, tetapi lebih ke membimbing. Karena penuh risiko, sehingga setiap usaha siswa harus kita beri apresiasi. Agar semangat untuk belajar terus meningkat.

Di dalam kelas, seorang guru haruslah profesional. Guru harus mampu menyampaikan materi sealami dan senyaman mungkin bagi siswa, agar siswa tidak frustasi karena tidak segera mengerti tentang apa yang dibahas oleh guru. Di sini muncullah joyful and meaningful teaching. Sebuah pembelajaran idealnya menyenangkan dan penuh makna. Guru memiliki peran besar di sini.

Cara untuk mengetahui spesies tumbuhan yang beranekaragam yaitu dengan indentifikasi dan inventarisasi. Identifikasi ialah mengungkapkan atau menetapkan identitas (jati diri) suatu tumbuhan, dalam hal ini adalah menentukan namanya yang benar dan tempatnya yang tepat dalam sistem klasifikasi (Tjitrosoepomo, 1989). Menurut Yulia (2008) inventarisasi tumbuhan merupakan langkah-langkah untuk menghitung jumlah spesies tumbuhan untuk mengetahui kelimpahan populasinya di dalam suatu habitat aslinya. Tahap ini dapat dijadikan perkiraan status spesies tumbuhan tertentu berdasarakan data di dalam habitat aslinya. Keanekaragaman yang melimpah berpotensi sebagai sumber belajar dan juga sebagai konservasi melalui bidang pendidikan. Keberadaan jenis-jenis 
tumbuhan di lingkungan merupakan objek real yang dapat dijadikan bahan pembelajaran di kelas khususnya pelajaran Biologi.

Terumbu karang merupakan salah satu ekosistem khas perairan tropik, dengan keanekaragaman jenis biota yang tinggi. Biota laut yang hidup di terumbu karang merupakan suatu komunitas yang terdiri dari berbagai tingkatan tropik, dimana masing-masing komponen dalam komunitas ini saling tergantung satu sama lain, sehingga membentuk suatu ekosistem yang lengkap. Salah satu jenis biota yang hidup di terumbu karang adalah ikan karang, yang umumnya memiliki tingkat keanekaragaman jenis yang tinggi pada ekosistem tersebut.

Beberapa hasil penelitian menunjukkan bahwa keberadaan ikan karang dipengaruhi oleh kondisi terumbu karang, dimana pada daerah yang terlindung (leeward) dan daerah terbuka (windward) biasanya terdapat terumbu karang yang mempunyai struktur morfologi yang berbeda. Dari perkiraan 12.000 spesies ikan laut dunia, kurang lebih 7.000 spesies $(58,3 \%)$ merupakan ikan yang hidup didaerah terumbu karang. Selanjutnya dikatakan bahwa wilayah antara bagian utara dan selatan Sulawesi hingga ujung barat Papua termasuk kepulaun Raja Ampat dan Halmahera merupakan wilayah dengan keanekaragaman hayati laut tertinggi, terutama untuk karang dan ikan karang (Utomo dkk., 2013).

\section{METODE PENELITIAN}

Secara sistematis langkah-langkah dalam artikel ilmiah dapat digambarkan sebagai berikut.

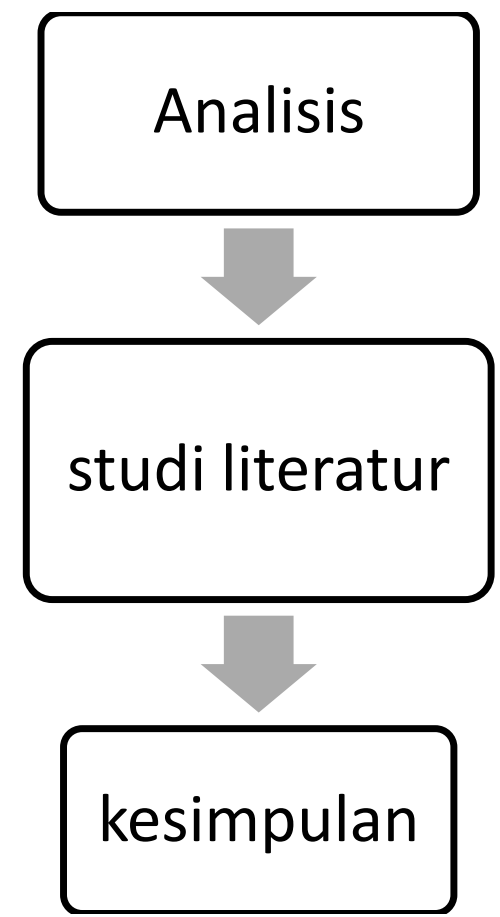

Pertama harus melakukan analisis terhadap permasalahan yang terjadi. Menganalisis sebab dan akibat, sejauh mana permasalahan tersebut berdampak pada keberhasilan pembelajaran pada peserta didik. Lalu mencari referensi dari berbagai sumber terpercaya dan relefan dengan permasalahn yang telah dianalisis. Sumber bisa diperoleh dari jurnal, buku, artikel laporan penelitian, situs-situs internet (bukan blogspot atau wordpress), dan pustaka. Tujuannya adalah memperkuat gagasan dan dasar teori. Selanjutnya menarik kesimpulan dari permasalahan dan literatur sehingga menjadi gagasan baru yang bermanfaat. 


\section{HASIL DAN PEMBAHASAN}

Wilayah jember memiliki ketinggian yang berbeda-beda. Wilayah bagian utara merupakan jajaran pegunungan yang ketinggiannya $>3000 \mathrm{~m}$. Sedangkan wilayah selatan merupakan daerah pesisir dan dataran rendah.dengan adanya situasi alam yang seperti itu dapat dimanfaatkan sebagai bahan ajar untuk para guru sains. Selain sebagai gambaran nyata di alam, pembelajaran outdoor juga dapat mengurangi tingkat stres pada peserta didik. Dalam kegiatan pembelajaran outdoor peserta didik bukan hanya diajak untuk berwisata tapi juga mendapatkan ilmu dari lingkungan yang mereka lihat.

Pendidik harus punya gambaran dan ide baru untuk menjadikan proses pembelajaran menjadi suatu hal yang menyenangkan. Guru sangat berpengaruh pada perubahan tingkat pengetahuan siswa. Guru bukanlah satu-satunya sumber belajar bagi siswa (teacher centered), tetapi yang lebih diharapkan adalah bahwa pembelajaran berpusat pada siswa (student centered). Dengan harapan agar aktivitas siswa dapat terarah dan sekaligus dapat mencapai tujuan pendidikan yang telah ditetapkan, maka proses belajar mengajar harus mengurangi proses belajar mengajar yang bersifat verbalisme, tetapi aktivitas mental dan fisik harus diutamakan (Arsyad, 2006:36).

Pada pembelajaran outdoor siswa bukan hanya diajak berimajinasi, tapi juga diajak membuktikan langsung tentang teoriteori yang telah disampaikan pada pembelajaran. Dengan begitu poses pembelajaran menjadi menyenangkan dan proses pemahaman peserta didik terhadap materi juga semakin mantap dan cepat. Peserta didik cenderung dapat mengingat apa yang mereka lakukan daripada yang mereka hafalkan.

Banyal hal yang dapat dijadikan sebagai bahan pembelajaran di wilayanh jember. Mulai dari keanekaragaman tumbuhan, keanekarahgaman hewan, kondisi geologi, jenis tanah, batuan, dan lain sebagainya. Yang menarik disini adalah situs megalitikum yang terdapat di kecamatan arjasa. Situs ini bukan hanya dapat dijadikan sebagai pembelajaran sejarah, tapi juga dapat digunakan sebagai pembelajaran IPA. Jika merambah ke materi batuan maka akan ditemukan bab tentang siklus batuan. Dari situ peserta didik diajak untuk mengidentifikasi jenis batuan yang ada pada situs tersebut.

Wilayah jember juga memiliki banyak variasi tumbuhan. Memang tak berbeda jauh dari daerah lainnya. Tapi ada yang menarik yang dapat dijadikan untuk pembelajaran, Yaitu tanaman poliploidi. Ketika satu sel terisi kromosom dua atau lebih maka dsebut poliploidi. Ketinggian tempat juga berpengaruh terhadap belangsungnya poliploidi. Hal tersebut sesuai dengan fakta bahwa wilayah jember memiliki ketinggian yang berbeda-beda. Dari situlah peserta didik dapat mengambil sampel tumbuhan pada dataran tinggi dan pada dataran rendah untu kemudian di amati perbedaannya.

Wilayah pesisir utara banyak terhadap biota laut yang dapat dipelajari. Jika ingin mempelajari tentang morfologi hewan laut, disinilah tempatnya. Keanekaragaman yang ada di pesisir memang jauh lebih menarik dibandingkan dengan di darat. Selain belajar, peserta didik juga dapat berwisata dan bermain. Peserta didik dinilai lebih cepat belajar jika berada pada situasi yang membuat mereka senang. Pemahaman materi juga jauh lebih mendalam dibandingkan sistem pembelajaran indoor. Sehingga peserta didikan bukan hanya mampu memahami teori, tapi juga wujud nyata dari materi yang disampaikan para pendidik.

Dari uraian diatas, peserta didik lebih menyukai belajar pada situasi yang membuat mereka nyaman dan senang. Selain itu, ketika pendidik memaparkan contoh nyata dari teori maka akan menambah pemahaman peserta didik. Adanya pembelajaran yang disertai wisata juga akan mengurangi stres yang umumnya dialami para peserta didik. Sengan demikian keberhasilan pembelajaran dalam diraih.

\section{SIMPULAN}

Kesimpulan dari artikel ini adalah pembelajaran akan lebih efektif jika 
pendidik mendemonstrasikan materi secara langsung. Para siswa akan lebih mudah memahami materi jika dalam kondisi yang membuat mereka senang. Stres juga dapat dihindari dengan adanya wisata edukasi. Alangkah baiknya jika pembelajaran seperti ini dapat diterapkan. Selain membuat peserta didik memahami konsep-konsep secara nyata, juga dapat membatu keberhasilan pendidikan.

\section{DAFTAR PUSTAKA}

Arsyad, A. 2006. Media Pembelajaran. Jakarta: PT Raja Grafindo Persada.

Tjitrosoepomo, G. 1989. Morfologi tumbuhan.Yogyakarta. Gajah Mada University Press.

Utomo, Suryo P.R., C. Ain., Supriharyono. 2013. Keanekaragaman Jenis Ikan Karang di Daerah Rataan dan Tubir pada Ekosistem Terumbu Karang di Legon Boyo, Taman Nasional Karimunjawa, Jepara. DIPONEGORO JOURNAL OF MAQUARES. 2(4): 81-90.

Yulia, N. D., Ruseani, N. S. 2008. Studi Habitat dan Inventarisasi Dendrobium capra J.J. Smith di Kabupaten Madiun dan Bojonegoro. BIODIVERSITAS. 9(3): 190-193 